\title{
Avoiding the AVoidable: Why State LaWs NeED to PROTECT KIDS FROM AIRBAGS
}

\author{
Mary Ann Chirba-Martin, J.D., Sc.D., M.P.H.
}

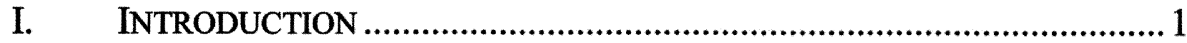

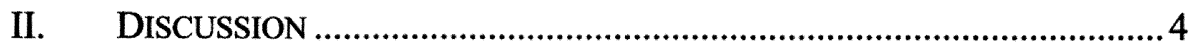

A. Dimensions of the Problem......................................................... 4

B. Efficacy and Feasibility of Rear Seating...................................... 6

C. Legislation as a Tool to Promote Child Safety ............................ 10

D. Current Child Passenger Laws and Strategies: Avoidable Risks

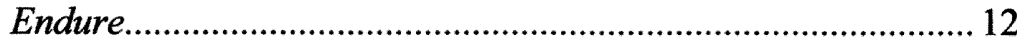

E. A Better Approach: Using Comprehensive Child Passenger

Laws to Avoid the Avoidable ........................................................ 17

F. Model Child Occupant Restraint and Seating Legislation ......... 19


\section{4} 6

2


tallize a dilemma that has plagued regulators, automotive engineers, and safety professionals since Congress' 1990 requirement that all new passenger vehicles, vans, light trucks and cars be equipped with passenger as well as driver airbags by model year $1999 .^{3}$

In the United States alone, over 138 million or $68 \%$ of cars and light trucks have driver airbags and more than 117 million (54.6\%) are also equipped with passenger airbags. ${ }^{4}$ Preliminary studies of actual crashes suggest that the passenger airbag has caused a net decline in fatality risk for adult passengers, yet child passengers have experienced a net increase in fatality risk due to the airbag. Most of the harm has been incurred by children under the age of 13 who were unrestrained or were not restrained properly when a crash occurred. An analysis of data from the U.S. Fatality Analysis Reporting System ("FARS") for calendar years 1989-1998 for children under 13 years of age indicated that front seat passenger side airbags pose an increased fatality risk of $31 \%$ for restrained children and $84 \%$ for unrestrained children. ${ }^{5}$ NHTSA estimates that absent effective countermeasures, as many as 100 additional children under age 13 will die each year when all passenger vehicles on the road are equipped with dual airbags. ${ }^{6}$ Thus, while airbags carry clear protective advantages for adult passengers, they portend more harm than good for child passengers.

A variety of responses are already in the works to mitigate the risks which airbags pose for children. For example, NHTSA has required or is considering, among other things, several design improvements to reduce risks to infants and children. ${ }^{7}$ By 1998 , some manufacturers had already begun installation of "smart" airbags which temper the force of deployment by as much as $35 \%$ based on the size of the occupant needing protection. Initial data show a significant reduction in childhood injury, ${ }^{8}$ but children

3. Federal Motor Vehicle Safety Standards: Occupant Crash Protection. 62 Fed. Reg. 807 (proposed Jan. 6, 1997) (codified at 49 C.F.R. pt. 571).

4. Insurance Institute for Highway Safety ("IIHS"), Highway Loss Data Institute, Airbag Statistics 2003, http://www.highwaysafety.org/safety_facts/airbags/stats.htm (last visited April 29, 2010). See also National Transportation SAFETY BOARD ("NTSB"), NTSB/SS-96/01, Safety Study: The Performance and Use of Child RestrainT Systems, Seat Belts and Airbags for Children in Passenger Vehicles Volume I: ANALYSIS (1996), available at http://www.ntsb.gov/publictn/1996/SS9601.pdf.

5. Roberta J. Glass, Maria Segui-Gomez, John D. Graham, Child Passenger Safety: Decisions About Seating Location, Airbag Exposure, and Restraint Use, 20 RISK ANALYSIS $521,521(2000)$.

6. NHTSA, Airbag Alert, http:/www.nhtsa.dot.gov/people/injury/airbag2/intro/ FRHelp.htm (last visited X). See also ChARLES J. KAHANE, NHTSA, DOT HS 808 470, Fatality REduction By AIR Bags: ANALYSES OF ACCIDENT Data THROUGH EARLY 1996 (1996) available at $\mathrm{http} / / / \mathrm{www} . \mathrm{nhtsa.gov} / \mathrm{Cars} /$ rules/regrev/evaluate/808470.html.

7. See e.g., 62 Fed. Reg. 2406, 2406 (proposed Nov. 21, 1997) on-off switch); 49 C.F.R. $\$ 571,571$ (Monitoring Performance of Advanced Airbags).

8. IIHS, $Q$ \&As: Airbags, http://www.iihs.org/research/qanda/airbags.html (last visited May 9, 2010). 
still suffer $90 \%$ of airbag related fatal and life threatening injuries. ${ }^{9}$ Consequently, despite their initial promise, depowered airbags may actually increase risk-taking through "moral hazard" whereby more parents allow their children to sit in the front passenger seat in the mistaken belief that depowered bags have eliminated the risk to children instead of lowering it only slightly. ${ }^{10}$

Beyond improving airbag technology, a number of additional solutions also come to mind: (1) do away with passenger airbags and, in doing so, surrender the device's lifesaving gains for adults; (2) redouble efforts to ensure that children are properly restrained in a safety belt and/or car seat, with the front seat moved back outside the airbag's deployment range; (3) allow parents to purchase a switch that can be used to turn off the airbag system when a child is seated in the front seat; (4) encourage or require vehicle manufacturers to install advanced or "smart" airbag systems that do not deploy on the passenger side if a child is seated up front. Currently, each of these options is being implemented or at least is receiving serious consideration by federal regulators and policy makers. ${ }^{11}$

This article advocates a more immediate and effective solution: amend state child passenger safety laws to prohibit (with a few exceptions) children from riding in the front seats of vehicles equipped with passenger airbags. Simply requiring children to be seated and properly restrained in the vehicle's back seat can reduce the odds of a child being seriously or fatally injured in a crash. ${ }^{12} \mathrm{~A}$ handful of states have already ventured in this direction with some early indications of achieving their intended effect. Nevertheless, even those statutes which explicitly address child seating location present numerous opportunities for continued improvement. Thus, a "Model" statute is offered, which seeks to maximize child passenger safety regarding airbags in particular and collisions in general. Although passing legislation inevitably raises political and logistical hurdles, the proposed statute promises substantial improvements in child passenger safety, especially since it will be easier to enforce than existing seat belt laws. It also builds on educational campaigns already in place which emphasize that the

9. See generally Kimberly M. Thompson, Maria Segui-Gomez, John D. Graham, Validating Benefit and Cost Estimates: The Case of Airbag Regulation, 22 RISK ANALYSIS 803 (2002).

10. See text, infra note 27. See generally, Matthew D. Adler, Against "Individual Risk": A Sympathetic Critique of Risk Assessment, 153 U. PA. L. REV. 1121 (2005).

11. Air Bag Deactivation, 49 Fed. Reb. 591 and 595 (proposed Aug. 6, 1996).

See also NHTSA, FMVSS No. 208, FInAL REGULATORY EVALUATION: ACTIONS TO REDUCE THE ADVERSE EFFECTS OF AIRBAGS: DEPOWERING (1997), available at http:// www.nhtsa.gov/cars/rules/rulings/80g/80g.html; Susan A. Ferguson, Update on Airbag Performance in the United States: Benefits and Problems (IIHS, Arlington, VA) 1996; Ferguson, S.A. 1996. Update on airbag performance in the United States: benefits and problems. Airbag 2000+: Third International Symposium on Sophisticated Car Occupant Systems, 7:7-17. Karlsruhe, Germany: Fraunhofer-Institut Fur Chemische Technologie (ICT).

12. See NHTSA, supra note 6. See also Kahane, supra note 6. 
rear seat is the safest place for children, and relies on growing public support for both the existence and enforcement of child seating laws. As such, the proposed statute offers a feasible and effective means to reduce the well proven, substantial in probability, and severe but largely avoidable risk which airbags currently pose to children.

\title{
II. Discussion
}

\section{A. Dimensions of the Problem}

Motor vehicle collisions have long been the leading cause of death for children aged 14 and under. ${ }^{13}$ In 2007 alone, approximately 5 children were killed and another 548 were injured in motor vehicle crashes each day. ${ }^{14}$ Compounding this tragedy is that many of these casualties could have been prevented by proper restraint use and rear seating, especially in vehicles equipped with front airbags. ${ }^{15}$ In its year 2000 Putting Children First Report, the National Transportation Safety Board described the mechanism of child airbag injury as follows:

\begin{abstract}
Airbags can kill or critically injure children in accidents that would have been survivable had the airbag not deployed. The insufficient distance between the restraint system and the inflating airbag, in combination with the speed and force at which an airbag can inflate, can be lethal to children. A deploying passenger-side airbag strikes the child in the head and neck as opposed to the upper torso where it typically contacts adults. Designing and certifying a system to protect all occupants using an average-sized adult male dummy has had tragic results for children. ${ }^{16}$
\end{abstract}

In 1991, Congress mandated that driver and front passenger airbags be included in all passenger cars manufactured on or after September 1997 and light trucks manufactured within the following year. ${ }^{17}$ By 2006 , there were 177 million driver airbag-equipped passenger vehicles on the road, with 162

13. Center for Disease Control and Prevention ("CDC"), Child Passenger Safety: Fact Sheet, http://www.cdc.gov/ncipc/factsheets/childpas.htm (last visited May 9, 2010).

14. NHTSA, DOT HS 810 987, TRAFFIC SAFETY FACTS: 2007 DATA: ChILDREN (2007), available at http://www-nrd.nhtsa.dot.gov/Pubs/810987.pdf.

15. See CDC, supra note 13.

16. NTSB, NTSB/SR-00/02, PUTTING CHILDREN FIRST (2002), available at http://www.ntsb.gov/Publictn/2000/SR0002.pdf.

17. The Intermodel Surface Transportation Act ("ISTEA"), 49 U.S.C. \& 30127(b). The Intermodal Surface Transportation Act of 1991 ("ISTEA"), 102 P.L. 240, 105 Stat. 1914 (1991); 49 U.S.C. $§ 30127$ (b) (2010). 
million of those containing front passenger airbags, too. ${ }^{18}$ From 1990 through 2007, airbags saved almost 24,000 lives; the large majority were drivers, but at least 4420 survivors were confirmed to have been riding in the front passenger seat. ${ }^{19}$ In addition to saving lives, though, airbags can also harm drivers and front passengers, especially children. ${ }^{20}$ Consequently, in the same time period of 1990 through 2007, front passenger airbags caused 13 adults to die and another 8 to sustain life-threatening injuries, while hurting a far greater number of children age 12 and under, with 180 confirmed and 9 unconfirmed fatalities, and 8 life threatening injuries. ${ }^{21}$

This particular risk is not surprising given how often children ride in the front seat and travel without proper restraint. In 1997, anywhere from one-third to one-half of American children age 12 and under traveled in the front seat, with the front seating position used more frequently by infants and toddlers than by younger children and pre-teens. ${ }^{22}$ In 1996, approximately $41 \%$ of child passenger fatalities for children age 12 and younger occurred in the front seat. $^{23}$ By 2006 , only $21 \%$ of passenger fatalities for this age group occurred in the front passenger location, but that still meant that 209 children died when not properly restrained and seated in the rear as recommended by NHTSA. ${ }^{24}$ Looking solely at front versus rear seat fatalities without specifically adjusting for airbags reveals that children in the front seat were about 1.5 times more likely to be fatally injured than children in rear seats. 25

To date, the data have consistently shown that, "[w] hether children are

18. NHTSA, DOT HS 810 807, TRAFFiC SAFETY FACTS: 2006 DATA: OCCUPANT ProteCtion 5 (2006), available at http://www-nrd.nhtsa.dot.gov/Pubs/810807.PDF.

19. NHTSA, SPEClal Crash INVESTIGATIONS: Counts OF Frontal AIR Bag Related FATALITIES AND SERIOUSLY INJURED PERSONS (2008), available at http://wwwnrd.nhtsa.dot.gov/Pubs/AB0108.pdf.

20. Roberta J. Glass, Maria Segui-Gomez, John D. Graham, Airbag Exposure and Restraint Use, 87 AM. J. PUB. HEALTh 1044, 1044-45 (1997)

21. Id. at Table 1.

22. NHTSA, Research Note: National Occupant Protection Use SuRvey - 1996 CONTROLLED INTERSECTION STUDY (1997), available at http://www-nrd.nhtsa.dot.gov/ Pubs/97.842.pdf. See also Lawrence E. Decina \& Kathleen Y. Knoebel, Child Safety Misuse Patterns in Four States, 29 ACCID. ANAL. PREV. 125 (1997); Harry Campbell, Sheena Macdonald \& Paul B. Richardson, High Levels of Incorrect Use of Car Seat Belts and Child Restrains in Fife - An Important and Unrecognized Road Safety Issue, 3 INJ. PREV. 17 (1997); David W. Eby, Lidia P. Kostyniuk, \& CARL ChristofF, University of Michigan, ANn ARbor, Transportation Research Institute, UMTRI-97-36, Child Restraint DEVICE USE AND MISUSE IN MICHIGAN (1997), available at http://www.umtri.umich.edu/library/ pdf/1997-36.pdf.

23. NHTSA, DOT HS 811 030, Traffic Safety Facts: Research Note: Fatality and Injury Trends Among Child Front-Seat Passenger Vehicle Occupants 12 and Younger (2008), available at $\mathrm{http}: / / \mathrm{www}-\mathrm{nrd}$.nhtsa.dot.gov/Pubs/811030.pdf.

24. Id.

25. NHTSA, DOT HS 809 784, CHILd PASSENGER FATALITIES AND INJURIES, BASED ON Restraint Use, Vehicle Type, Seat Position, and Number of Vehicles in the Crash 4 (2005), available at http://www-nrd.nhtsa.dot.gov/Pubs/809784.PDF. 
restrained or unrestrained, they are safer when traveling in the second seat... [although the] relative protection provided by traveling in the second seat (compared to the front passenger seat) is lessened when the passenger is unrestrained." 26 Nevertheless, many children continue to travel in the front and, therefore, remain unnecessarily exposed to the potentially life-threatening risk of an airbag related injury. What is even more alarming is that a growing number may be doing so with no restraints at all. Depending on age subgroup, NHTSA recently estimated that approximately 5 to $10 \%$ of the country's 61 million children ${ }^{27}$ still travel in the front passenger seat and that in $2006,15 \%$ of front seated children used no restraint at all. For reasons that have yet to be explained, this figure jumped dramatically to $25 \%$ of front seated children - perhaps 1.5 million of them - being completely unrestrained in $2007 .^{28}$

\section{B. Efficacy and Feasibility of Rear Seating}

A shortage of seating capacity in the rear does not explain why American children frequently ride in front. In a study of 17,000 fatal crashes from 1985 through 1996, in which a child (dead or surviving) was seated in the front, the rear seat was completely empty in $65 \%$ of the cases and at least one rear seat was unused in $96 \%$ of cases. ${ }^{29}$ In continental Europe, law and custom have cultivated markedly different seating patterns among children since at least the mid-1970's. An observational survey comparing child seating behaviors in three European cities (Frankfurt, Germany; Paris, France; Brussels, Belgium) to behaviors in two America cities (Boston, Massachusetts; New Orleans, Louisiana) found that children in America were three times more likely than European children to ride in the front seat. $^{30}$ Even within the United States, child seating patterns appear to vary

26. Id. at 51. See also Roberta J. Glass \& John D. Graham, Kids at Risk: Where American Children Sit in Passenger Vehicles, 30 J. SAFETY RES. 17 (1999); Elisa R. Braver, Randy Whitfield \& Susan A. Ferguson, Seating Positions and Children's Risk of Dying in Motor Vehicle Crashes, 4 INJ. PREV. 181 (1998); KAHANE, supra note 6.

27. See NHTSA, Traffic Safety Facts 2007 Data: Children, supra note 13 at 1 (estimating the U.S. population of children age 14 and younger to be 61 million. That between 5 and $10 \%$ of these children ride in the front seat is based on data reported in NHTSA Traffic Safety Facts: Child Restraint use in 2007 - Overall Results).

28. NHTSA, Traffic Safety Facts: Child Restraint Use in 2007 - Overall Results 2 (2008), http://www.nhtsa.dot.gov/portal/site/nhtsa/menuitem.6a6eaf83cf719ad24ec86e 10dba046a0/.

29. Roberta J. Glass, \& John D. Graham, Kids at Risk: Where American Children Sit in Passenger Vehicles, 30 J. SAFETY RES. 17-24 (1999); Donald F. Huelke \& Charles P. Compton, The Effects of Seat Belts on Injury Severity of Front and Rear Seat Occupants in the Same Frontal Crash, 27 ACCID. ANAL. PREV. 835-838 (1995).

30. Maria Segui-Gomez, Roberta J. Glass, John D. Graham, Where Children Sit in Motor Vehicles: a Comparison of Selected European and American Cities, 4 INJ. PrEv.98-102 (1998); Maryvonne Dejeames, Claes Tingvall, Ake Nygren, Effectiveness of Safety Belt Use Laws: A Multinational Examination, U.S. DEPT. OF TRANSPORTATION (1986), available at http://www.eric.ed.gov/ERICDocs/data/ericdocs 2 sql/content_storage_ 
by state with some states having twice as many children in the front seat as others. ${ }^{31}$ For example, a 2005 study of observed seat belt use measured a low of $49.6 \%$ in New Hampshire to a high of $95.2 \%$ in the state of Washington. $^{32}$

In the United States, numerous public education programs designed to encourage adults to seat children in the back of passenger vehicles have been underway for several years. NHTSA has incorporated information about seating location (with varying degrees of emphasis) into its "Campaign Safe and Sober" and its "Child Transportation Safety Tips" literature. ${ }^{33}$ The Insurance Institute for Highway Safety's (IIHS) Kids and Airbags campaign is another effort to influence seating behavior through education. ${ }^{34}$ A number of states launched Kids in Back promotions such as that of Massachusetts in May 1998, but they varied widely in content and duration. Some of the tag lines sought to be clever (such as NHTSA's suggested "for safety's sake ... the back seat is the best seat") while other messages were far more blunt ("the airbag that saves your life could kill your child," again offered by NHTSA).

Consumer education efforts have not consistently integrated seating position with seat belt usage. Instead, they have tended to discuss either seat belts or seat position, but not both - at least not on an enduring basis. For instance, the 1996 "Presidential Initiative for Increasing Seat Belt Use Nationwide" called for state laws to effectuate "comprehensive child passenger safety" but made no mention of seating location. ${ }^{35}$ Perhaps this oversight can be explained by a lack of data in 1996 to link front seating with airbag-related injuries. ${ }^{36}$ However, the National Safety Council's web description of its Air Bag and Seat Belt Safety Campaign's national "Click it or Ticket Mobilization" continues to say nothing about airbags or rear seating. $^{37}$

01/0000019b/80/1c/2b/1d.pdf. ; Improper Use of Child Safety Seats, Kentucky 1996, 47 MORBIDITY \& MORTALITY WKLY. REP. 541-44 (1998), available at ftp://fp.cdc.gov/pub/ Publications/mmwr/wk/ mm4726.pdf (last visited Apr. 17, 2010).

31. Id. See Glass, Gomez \& Graham, supra note 19, at Table 1; Maria Segui-Gomez, et al., Where Children Sit in Cars: The Impact of Rhode Island's New Legislation, 91 AM. J. PUB. HEALTH 311 (2001).

32. NHTSA, How States Achieve High Seat Belt Use Rates Table 31 (2008).

33. NHTSA, Campaign Safe \& Sober, http://www.nhtsa.dot.gov/people/ outreach/SafeSobr/; NHTSA, Child Transportation Safety Tips, Tip \#9 Airbag Safety, www.nhtsa.gov/people/injury/childps/newtips/. See also IIHS-HLDS, Kids \& Airbags, www.highwaysafety.org/safety-facts/airbags/kids-airbags/kids-airbags.htm.

34. IIHS, Kids \& Airbags, http://www.iihs.org/research/topics/airbags.html. In contrast, the 1996 Mayo Health Program's Airbags and Infant Car Seats: They Don't Mix campaign is no longer available on its website.

35. Presidential Initiative for Increasing Seat Belt Use Nationwide, http://www.nhtsa.dot.gov/people/injury/airbags/Archive-04/PresBelt/fullreport.html (last visited Apr. 17, 2010).

36. Id.

37. NHTSA, Click it or Ticket, http://www.nhtsa.gov/portal/site/nhtsa/menuitem. ce4a601cdfe97fc239d17110cba046a0/ (2009). 
A detailed example of the relative de-emphasis of seating location can be found in the National Safe Kids Campaign's February 2001 grading of state child restraint laws. ${ }^{38}$ It assigned a grade of " $F$ " to 24 states, " $D$ " to 18 states plus the District of Columbia, "C" to 5 states, and only one " $B$ " (to Florida) and "A" (to California). ${ }^{39}$ However, the seven criteria on which scoring were based took no express account of seating location. ${ }^{40}$ Thus, while the organization supports rear seating mandates, it focuses exclusively on proper restraints for various age groups and says nothing about seating location on its introductory webpage. ${ }^{41}$ Despite recent enhancements to such educational initiatives, ${ }^{42}$ these messages must be consistently and tightly integrated, both because they are necessary complements of one another in reducing crash-related injuries and because integration will maximize efficient communication to the target audience.

Automotive manufacturers have a particularly acute interest in reducing airbag injuries for all age groups since they are required by federal law to install passenger airbags but face liability exposure if an airbag causes injury. ${ }^{43}$ Thus, car makers can rightfully view airbags as an enduring Catch-22. Prior to federally mandated airbag installation, many product liability suits asserted manufacturer liability for the failure to install airbags. $^{44}$ Once installed, airbags engendered a new generation of product defect claims based on equipment malfunction (i.e., failure to deploy or inappropriate deployment in a collision) as well as claims regarding the special hazards which airbags pose for children and small-statured adults. ${ }^{45}$ Consequently, automakers, insurers, and airbag suppliers made their own efforts to incorporate the "kids in back" message into their advertising campaigns. These efforts began in 1996 when the National Safety Council, NHTSA, and the National Transportation Safety Board collectively hosted a national "Call to Action" conference to encourage public and private entities to focus on reducing child airbag injuries. ${ }^{46}$ As data accumulated, the

38. See National Safe Kids Campaign, Child Passengers at Risk in America: A NAtional Rating of Child OCCUPANT PROTECTION LAws (2001), http://www.usa.safekids. org/content_documents/ACF15F4.pdf.

39. $\overline{I d}$. at 5 .

40. Id. at 4 .

41. National Safe Kids Campaign, Child Passenger Safety, http://www.usa.safekids. org/skbu/cps/index.html.

42. E.g., Nat'l Safety Council, Air Bag and Seat Belt Safety Campaign "Operations $A B S^{\prime \prime}$, http://www.nsc.org/airbag.aspx

43. See Cynthia M. Certo, Changes to Safety Standard 208: Deploying an (Air) Bag Full of Product Liability Claims? 67 TEMP. L. REV. 673 (1994).

44. See, e.g., Timothy Wilton, Federalism Issues in "No Airbag" Tort Claims: Preemption and Reciprocal Comity, 61 NoTrE DAME L. REV. 1 (1986).

45. See, e.g., Thompson, supra note 8; NHTA, Traffic Safety Facts 2007 Data: Children, supranote 13.

46. See, e.g., Jim Hall, Chairman, Natl. Transportation Safety Board, NHTSA/ National Safety Council Conference, Safety Belts, Airbags \& Passenger Safety: A Call to Action (Jan. 16, 1996) http://www.ntsb.gov/Speeches/former/hall/jh960116.htm. 
spring of 1998 saw a coordinated national media blitz by law enforcement organizations, automotive manufacturers and suppliers to promote the dual messages of "buckle up" and "kids in back.",47 The U.S. Airbag Coalition, managed by the U.S. National Safety Council, played an early role in coordinating educational efforts in the public and private sectors. ${ }^{48}$ NHTSA's $^{2}$ multi-year Buckle Up America initiative built on this consolidated and coordinated approach by encouraging partnerships among government, industry, and consumer groups to enhance data collection and improve the availability and quality of information. ${ }^{49}$ The growth in law enforcement interest was particularly dramatic, with 1000 agencies becoming involved by 1997 , eventually growing to over 12,000 by $2002 .^{50}$

Such public information campaigns should be commended for focusing public attention on airbags and child safety. These campaigns have undoubtedly contributed to yearly reductions in airbag related child fatalities. $^{51}$ They are also an essential tool in dispelling misconceptions about the need to use proper restraints and the safety advantages of the rear seat. By themselves, however, information and educational campaigns should not be expected to achieve adequate and lasting changes in how children are seated in vehicles. Indeed, a 2005 National Safety Council sponsored report showed that front seat deaths for children increased prior to 1995 , but declined by $67 \%$ from 1996 through $2003 .{ }^{52}$ These gains were primarily attributed to the effectiveness of using public education and law to promote rear seating, as opposed to making front travel safer because of side or depowered frontal airbags. ${ }^{53}$ Accordingly, as important as technological improvements are, public safety campaigns and legislative enactment and enforcement must be viewed as far more immediate and effective tools for reducing front seat injuries.

Thus, a more successful behavioral intervention in the safety field usually entails augmenting often inconsistent public safety campaigns with

47. See, e.g., Maria Segui-Gomez, Evaluating Interventions that Promote the Use of Rear Seats for Children, 16 AM. J. PREvENTIVE MED. 23 (1998).

48. U.S. National Safety Council Air Bag Seat Belt Safety Campaign, http://www.nsc. org/partners/airabout.aspx.

49. U.S. Dept. of Transportation Buckle Up America Initiative, http://www.nhtsa.dot. gov/people/outreach/safedige/summer1999/su9950.htm.

50. James L. Nichols, Donna Glassbrenner, \& Richard P. Compton, The Impact of a Nationwide Effort to Reduce Airbag-Related Deaths Among Children: An Examination of Fatality Trends Among Younger and Older Age Groups, 36 J. SAFETY RES. 309 (2005).

51. NHTSA, Counts of Frontal Airbag Related Fatalities and Seriously Injured Persons, available at http://www.nrd.nhtsa.dot.gov/pubs/AB0108.pdf (hereinafter "NHTSA, Counts") ; Stephanie Zaza, et al., Reviews of Evidence Regarding Interventions to Increase Use of Child Safety Seats, 21 AM. J. OF PREventive MED. 31 (2001). See also Sullivan v. Ford Motor Co., 2000 U.S. Dist. LEXIS 4114 (S.D. N.Y. 2000); Wheeler v. Chrysler Corp., 2000 U.S. Dist. LEXIS 2725 (N.D. Ill. Feb. 29, 2000).

52. See Nichols, supra note 49 , at 318 . kid.pdf.

53. Id. See also http://www-nrd.nhtsa.dot.gov/pdf/nrd-01/SAE/SAE2003/Kindelberger 
an enduring legal requirement accompanied by intensive and visible police enforcement. Again, experiences in both continental Europe and the states bear this out. ${ }^{54}$ Without the deterrent and moral force of a legal requirement, it is difficult for education alone to convert attitudinal changes into lasting improvements in risk-reducing behaviors. The need for a legal requirement will become even more apparent in the years ahead as vehicles with passenger airbags are resold in the used car market to owners who may be less aware of important safety concerns. ${ }^{55}$ If laws about child seating behaviors do not change, it may become more difficult for auto makers and advocates to justify continued investments in education and information.

\section{Legislation as a Tool to Promote Child Safety}

Rear seating has consistently been shown to reduce a child's risk of injury whether or not a passenger-side airbag is present, and legal mandates have just as consistently proved to be most effective in altering restraint use. ${ }^{56}$ Therefore, a statutory rear-seating requirement would seem to be an obvious and valuable way of decreasing child airbag injuries. Nevertheless, it is important to recognize that such measures are likely to encounter a significant degree of generalized opposition to government intrusion into the parent-child relationship. ${ }^{57}$ As a result, opponents may characterize legal directives to parents concerning where and how to seat their child in the privacy of their own car as government patriarchy at its most overreaching.

While any legislative proposal will encounter resistance, child safety advocates and state legislators are on especially firm ground in acting to improve child safety through mandatory rear seating. Federal regulations, along with state product liability and "lemon" laws already create a strong, if not pervasive presence in the field of automotive safety. ${ }^{58}$ Plus, through its parens patriae power, the state has a special obligation to protect the health and safety of children even if it means occasionally overriding parental decisions. ${ }^{59}$ Parens patriae authority permits a state to act in place of

54. See NHTSA, Child Fatalities, supra note 24.

55. See National SAFe Kids CAMPAign, Child Passengers at Risk IN AMERICA, supra note 38 and accompanying text.

56. Maria Segui-Gomez et al., Where Children Sit in Cars: The Impact of Rhode Island's New Legislation, 91 AM. J. PuB. HEALTH 311 (2001).

57. See generally Gregory Thomas, The Parent/Child Relationship: Limitations on Parens Patriae: The State and the Parent/Child Relationship, 16 J. CONTEMP. LEGAL ISSUES 51 (2007).

58. See, e.g., Kurt B. Caldwell, Automobile Passive Restraint Claims Post-Cipollone: An End to the Federal Preemption Defense, 46 BAYLOR L. REV. 141 (1994); Kevin M. McDonald, Federal Preemption of Automotive Recalls: A Case of Too Many Backseat Drivers?, 71 TENN. L. REV. 471 (2004). Literally thousands of federal motor vehicle safety standards are contained in 49 C.F.R. 571.

59. See Thompson, supra note 8; NHTA, Traffic Safety Facts 2007 Data: Children, supra note 13. 
the parent when either 1) the parent proves to be unfit to act on his child's behalf, or 2) the state essentially decides that there is only one "right answer" since any other choice would place the child at a risk of harm which the state, through its courts or legislators, has deemed intolerable. ${ }^{60}$ The exercise of parens patriae authority underlies the requirement that children must attend school and receive certain vaccines as a condition of attending public school. Even parents who wish to "home school" their children must comply with state standards. In extreme cases of parental abuse or neglect, the state will go so far as to remove the child from the family with formal custody vested in the state. Numerous judicial decisions have invoked $p a-$ rens patriae power in requiring a child to receive blood transfusions or other life saving medical treatment over parental objections. As the United States Supreme Court explained over 50 years ago in Prince v. Massachusetts:

Parents may be free to become martyrs themselves. But it does not follow that they are free, in identical circumstances, to make martyrs of their children before they have reached the age of full and legal discretion when they can make that choice for themselves. ${ }^{61}$

In the context of motor vehicle safety, a legislative or regulatory entity essentially decides that only behavior which comports with the government mandate sufficiently protects the child's best interests. As such, it becomes the only available legal option and, therefore, trumps a parent's right to make a different choice for the child. In the context of children and airbags, law makers can rely on the Prince v. Massachusetts rationale to require rear seating because parents should not be free to expose their children to legally proscribed risks even if they might decide otherwise for themselves. Nevertheless, some risks may be too slight or unsubstantiated (e.g., rear center vs. rear outboard seating of children) or too enmeshed in complex child-rearing issues (e.g., a child's dietary patterns) to justify state intervention. However where, as here, the risk to children is well-proven, substantial in both probability and severity, easily preventable, and affected by

60. Typically, the state steps in and renders a decision using either the "best interests" or "substituted judgment" standard. Under the best interests analysis, the state simply evaluates which option is most commensurate with the child's objective best interests. The substituted judgment test requires the state to assess how the child, a legal incompetent, would decide if she were competent. Fortunately, at the policy level, it is possible to avoid the logical complexities of the substituted judgment test. In enacting child-protective legislation or promulgating regulations under such laws, the best interests implicitly guide decision-making.

61. 321 U.S. 158,170 (1944). See also Santosky v. Kramer, 455 U.S. 745, 766 (1982) (acknowledging a state's "parens patriae interest in preserving and promoting the welfare of the child"). 
extensive laws and regulations already "on the books," the case for state intervention into parental choice is compelling. In this context, policy need not rest solely on data. Rather, longstanding legal and political precepts require well-designed and consistently enforced laws to reduce child airbagrelated injuries and fatalities.

\section{Current Child Passenger Laws and Strategies: Avoidable Risks Endure}

Given the special role of government in protecting children, and federal funding incentives to do so in the context of motor vehicle safety, it is not surprising that every state has enacted some form of child passenger legislation. Yet, none of these statutes adequately protect child passengers since all contain at least one and usually more of seven deadly gaps in state child seating laws.

First, state laws vary in the age of the child required to be restrained (without regard to seating location), but most only cover children aged 7 and under. This approach obviously leaves a substantial population of children completely unprotected by such laws. ${ }^{62}$ Second, the consequences for non-compliance tend to be slight, with small financial penalties ${ }^{63}$ and no duty to report violations to insurers. ${ }^{64}$ Failure to use seat belts is commonly inadmissible in litigation, particularly as evidence of contributory or comparative negligence or recklessness. ${ }^{65}$ Third, state laws often apply only to vehicles registered in that state, further curtailing their effectiveness. ${ }^{66}$ Fourth, many child restraint laws are vague in only requiring "proper" restraint without defining how that term is to be interpreted or enforced. ${ }^{67} \mathrm{~A}$ number of states do require the meaning of "proper" to be determined by reference to federal safety standards. ${ }^{68}$ As discussed below, linking state law to federal safety standards is an important step in building more effective child passenger safety laws since it permits state protections to evolve as the science of motor vehicle safety improves.

Fifth, because the large majority of state child occupant laws focus on

62. E.g., Ala. Code $\S$ 32-5-222(a) (2009); CAL. VEH. CodE $\S 27315(\mathrm{e})(2009)$; VA.. CODE ANN. § 46.2-1095(A) (2009).

63. E.g., TenN. Code. ANN. $§ 55-9-602$ (2009) (\$50); Mo. REV. Stat. $\$ 307.179$ (2009) (\$50 plus court costs).

64. Typically, events are not reportable if they do not involve personal injury or property damage of some significant dollar amount. See, e.g., Susan A. Ferguson, Donald W. Reinfurt \&Allan F. Williams, Survey of Passenger and Driver Attitudes in Airbag Deployment Crashes, 28 J. SAFETY RES. 55 (1997).

65. E.g., R.I. GEN. LAWS $\S 31-22-22$ (2009).

66. E.g., HAW. REV. STAT. § 291-11.5 (2009). See also, NHTSA, Summary of Vehicle Occupant Protection Laws, http://www.nhtsa.dot.gov/ people/injury/airbags/VehOccProtectionLaws.pdf.

67. E.g., Haw. REV. StaT. § 291-11.5 (2009); CAL. VeH. CodE § 27360.5(a) (2009); MASS. GEN. LAWS ch. 90, § 7AA.(2009)

68. E.g., La. Rev. Stat. Ann. § 32:295 (2009); Ariz. Rev. Stat. Ann. § 28-907 (2009). 
seat belts without reference to rear or back seating, they are difficult to enforce. $^{69}$ A law enforcement officer standing outside of a car - especially if some distance away from it -- may not notice the absence or improper use of a seat belt if the child is sitting still. "Improper" belting or restraint is even more difficult to detect through observation alone, unlike the more obvious location of the child in a vehicle. Consequently, seating location mandates would be much easier to enforce. A sixth major disadvantage of many state seat belt laws is that they impede enforcement by simply describing seating requirements without specifically charging the driver with ensuring compliance. ${ }^{70}$ Seventh, and finally, a sizeable number of states continue to employ "secondary" as opposed to "primary" enforcement. "Primary" enforcement allows a police officer to stop and issue a citation upon observation of an unbelted occupant while "secondary" enforcement, the more common of the two, permits a citation only if the car has been stopped for another infraction. ${ }^{71}$ Failure to wear a seat belt is not, in and of itself, a sufficient ground to stop a car and write a ticket in secondary-enforcement jurisdictions.

Primarily enforceable seat belt laws clearly work, and a growing number of states are converting from secondary to primary enforcement, rising from 18 before 2004 to 25 (plus the District of Columbia and Puerto Rico) as of 2006. ${ }^{72}$ The most impressive gains in both adult and child belt usage have been realized in those states which have moved toward aggressive primary enforcement of their seat belt laws in conjunction with media education. ${ }^{73}$ A typical example is the state of Washington which experienced a $13.9 \%$ reduction in overall motor vehicle occupant fatalities following its passage of a primarily enforceable seat belt law. ${ }^{74}$ NHTSA reports that in $2008,88 \%$ of motor vehicle occupants used seat belts in primary law states

69. E.g., ARK. Code ANN. § 27-34-104 (2009); Nev. Rev. STAT. § 484.474 (2009); 75 PA. CONS. STAT. $\S 4581$ (2009).

70. E.g., OR. Rev. STAT. $\S 811.210$ (2009). Compare CEJUn LIUET, ET AL., NHTSA, Traffic Safety Facts Research Note: States With Primary Enforcement Laws Have Lower Fatality Rates (2006), available at http://www-nrd.nhtsa.dot.gov/Pubs/810557.PDF with NHTSA, Traffic Safety Facts Research Note:States With Primary Enforcement Laws Have Lower Fatality Rates (Updated) (2008), available at http://wwwnrd.nhtsa.dot.gov/Pubs/810921.pdf.

71. Id. and accompanying text.

72. Natl. Safety Council, Operation ABC Mobilization: Encouraging Trends in Strengthening Safety Laws (revised 2002), http://www.nsc.org/partners/encourge.aspx.

73. See NHTSA, Presidential Initiative for Increasing Seat Belt Use Nationwide, $\mathrm{http} / / / \mathrm{www} . n$ htsa.dot.gov/people/injury/airbags/Archive-04/PresBelt/index.html.

74. See generally, NHTSA, Primary Enforcement Saves Lives: The Case for Upgrading Secondary Safety Belt Laws, http://www.nhtsa.dot.gov/ people/injury/enforce/ PrimaryEnforcement/images/PrimaryEnforcement.pdf; NHTSA, Traffic Safety Facts: Strengthening Safety Belt Use Laws-Increase Belt Use, Decrease Crash Fatalities and Injuries, http://www.nhtsa.dot.gov/people/injury/new-fact-sheet03/Seat beltLaws.pdf (2004). 
while only $75 \%$ did so in secondary law states. ${ }^{75}$ The difference is especially significant when it comes to children since child restraint use increases with adult use even without specifically amending the child restraint law. ${ }^{76}$ Nevertheless, while child safety seat laws are primarily enforceable in all states, only half of all states permit primary enforcement of their seat belt laws. As a result, in half of all states, children who no longer use car seats are deprived of the benefits of primary enforcement. ${ }^{77}$

Improving a state's general seat belt laws can improve the safety of child passengers and should have some impact on frontal airbag injuries, but it cannot compensate for existing weaknesses in the child passenger laws themselves. In terms of reducing frontal airbag injuries to children, the central problem with the large majority of state child passenger safety laws is their failure to make any mention of rear seating for children. To date, only fourteen state laws express some form of preference or limited requirement for rear seating; however, to varying degrees, even these measures leave most children exposed to frontal airbag injury. ${ }^{78}$ For instance, California and Georgia require use of available rear seating without regard to frontal airbag activation, but only for children five years and younger, leaving older but equally vulnerable children at risk. ${ }^{79}$ Vermont only requires rear seating for children 1 year or younger or under 20 pounds unless the front airbag is deactivated. ${ }^{80}$ In contrast, Louisiana and Idaho have no rear seating requirement although they permit but do not require seating children, aged 18 months to under 4 or 5 years, in the rear with a seat belt, as an alternative to using a child car seat in the front passenger location. ${ }^{81}$ Clearly, these provisions are not designed to address the safe adult/endangered child dilemma of airbags.

In July 1997, Rhode Island took the lead in using law to reduce child airbag injuries when it revised its child restraint law to require rear seating, initially for children through age 5 and now age 7 (improving upon an earlier bill's use of an age 3 cut-off). ${ }^{82}$ Front seating, with a seat belt or safety seat, is permitted for such children if the vehicle has no rear seat or if all rear seats are occupied by other children. An observational study conducted in the year following enactment of the Rhode Island statute indicated that

75. NHTSA, Traffic Safety Facts Research Note: Seat Belt Use in 2008 - Overall Results 1 (2008), http://www-nrd.nhtsa.dot.gov/ Pubs/811036.PDF.

76. See, e.g., Julie Russell, Marcie-Jo Kresnow, Robert Brackbill, The Effect of Adult Belt Laws and Other Factors on Restraint Use for Children Under Age 11, 26 ACCID. ANAL. \& PREV. 287 (1993).

77. See Caldwell, supra note 57, McDonald, supra note 57 and accompanying text.

78. IIHS, Child Restraint Laws, http://www.iihs.org/laws/ChildRestraint.aspx

79. CAL. VEH. CODE $\$ 27360$ (a) (2007); GA. CODE ANN. §40-8-76(b)(1)(B) (2009).

80. VT. Stat. ANN. tit. 23, \$1258(a)(1) (2009).

81. IDAHO CODE ANN. § 49-672 (2009); LA. REV. STAT. ANN. § 32-295 (2009).

82. See supra note 51. See also R.I. GEN. LAWS $\$ 31.22 .22(a)(1)(2000)$, IDAHO CODE ANN. § 49-672 (2001); La. Rev. Stat. Ann. § 32:295. 
the law was achieving significant gains in increasing rear seating. ${ }^{83}$ While laudable as an early effort at rear seating legislation, the Rhode Island statute is too limited, most notably because it does not protect children older than 7. Unfortunately, when North Carolina amended its child restraint statute in 1999, it followed Rhode Island's initial approach of restricting its rear seating mandate to children less than 5 years of age of 40 pounds in weight. $^{84}$ New Mexico and South Carolina followed suit in $2001 .^{85}$

Delaware took a somewhat better approach when, in 1998, it enacted a statute requiring any child under 12 years of age and less than 65 inches in height to be seated in the rear of vehicles equipped with front passenger-side airbags. ${ }^{86}$ The front seat prohibition does not apply, however, if the airbag has been deliberately rendered inoperable or has been "specifically designed or modified by the vehicle's manufacturer for use by children and small adults." 87 The Delaware law obviously improves upon its Rhode Island predecessor by protecting a broader age range of children and the state of Washington has taken a similar approach. ${ }^{88}$ Nevertheless, while Delaware has so far formulated the best legislative response to the special dangers which airbags create for children, it also fails to optimize child safety. Its most obvious shortcoming is that, initially, it only imposed a maximum fine of just $\$ 28.75$ per offense. While this has since been increased to $\$ 75$, it is still quite modest given that an offense is based on the event of being cited rather than the number of improperly seated children per event. More significantly, the statute applies solely to vehicles with functional front passenger airbags and, thus, does nothing to diminish the dangers to front seated children in vehicles without airbags. ${ }^{89}$

A more troubling aspect of the Delaware law is its strategy for keeping pace with technological innovation. Statutes should be designed to evolve over time. This law, however, permits front seating if the airbag is "specifically designed or modified by the vehicle's manufacturer for use by children and small adults." When first passed, the law was scheduled to "sunset" or lose effect on January 1, 2003 "provided new federal regulations regarding safer deployment of airbags are in effect." "90 "Safer" is a relative term which is only further clouded by the statute's vague use of "regarding." The statute's framers seemed to assume that any design modifications or new federal regulations which somehow "regard" "safer" airbag deployment will, without more, necessarily reduce airbag child

83. Maria Segui-Gomez, et al, Where Children Sit in Cars: The Impact of Rhode Island's New Legislation, 91 Am. J. Pub. Health 311, 311 (2001).

84. N.C. Gen. Stat. § 20-137.1(2000).

85. N.M. State $\S 66-7-369 B(2001)$; S.C. Code Ann. $\S 65(1)$.

86. DEL. CODE ANN. Title 21, § 4803 (2004).

87. Id.

88. WASH. REV. CODE $§ 46.61 .687$ (2001).

89. Del. Code ANN. Title 21, § 4803 (2004).

90. Id. 
passenger risks to some tolerable level. New or amended federal safety standards may indeed abate airbag-induced risks to child passengers. Such changes, however, will not necessarily erase such risks nor will they negate the overall benefits of seating children in the rear instead of the front of a car. Fortunately, the statute was reauthorized and currently contains no sunset provision. ${ }^{91}$ Indeed, if the experience with airbags to date has taught policy makers anything, it should be that new technology and/or federal requirements can reduce some risks while unintentionally creating new ones. Thus, legislators must be wary of designing a statute to recede automatically upon future safety "improvements."

Europe's experience with seating location mandates is also instructive. Between 1975 and the early 1990 's, most countries in continental Europe required children to ride in the rear seats. The age cut-off was 12 in Germany; and 10 in France and Belgium. At the suggestion of the European Commission, these laws were gradually liberalized in the 1990 's to permit children in the front if they are restrained properly. ${ }^{92}$ The liberalization occurred prior to the introduction of passenger airbags, which are penetrating the European market slowly due to the absence of regulation and the high rates of safety belt users. The European Commission may be forced to revisit this issue as the passenger airbag becomes more prevalent.

Thus, existing child passenger safety laws in the United States are not well designed to protect children from passenger airbags. NHTSA has advocated for improvements to state laws, but has not highlighted the benefits of rear seating mandates. ${ }^{93}$ Yet, legislative change (be it a major overhaul or incremental fine tuning) should require rear seating as a far simpler approach than the current reliance on "proper" restraint if only because it is so much easier for a police officer to observe seating position than it is to detect improper restraint use. Because rear seating requirements are necessary to reduce fatality and injury rates associated with front airbags, they must not be overlooked or separated from other legislative and educational efforts to increase seat belt use.

Several strategies have already emerged to remediate the previously described deficits in state laws. They include: 1) repeal the passenger airbag requirement; 2) promote proper restraint use by children in the front and/or rear seat; 3 ) allow parents to purchase an airbag cut-off switch for the passenger airbag; and 4) encourage or require advanced airbag designs that protect children. While laudable in their objectives, these strategies are as flawed as the laws they seek to improve.

Repealing the passenger airbag requirement would be an overreaction since the technology appears to be saving a significant number of adult

91. Id.

92. Id.

93. See supra note 40. 
lives in a cost-effective manner. Even if the airbag requirement were repealed, a case for child seating laws could still be made for the many millions of airbag-equipped vehicles already in use and the future vehicles that manufacturers would elect to equip with passenger airbags as optional or standard equipment. Concerted efforts to promote proper restraint use among children are urgently needed but, as already explained, focusing solely on restraint while deemphasizing or ignoring seating location misses important gains in improving child passenger safety. Moreover, it would still be easier for police to enforce child restraint-use laws if they could stop any vehicle with a child located in the front seat. For these reasons, a combination of primary enforcement of child-seating and child-restraint laws is the most promising behavioral strategy.

NHTSA has permitted vehicle owners in eligible categories to purchase manual cut-off switches to deactivate an airbag when a child is riding in front. Since January 1998, dealers and repair shops can install on-off switches but only if the vehicle owner has first obtained a letter of authorization from NHTSA. To obtain authorization, the owner must show that the passenger side would carry either: 1) individuals with medical conditions where the risks of airbag deployment exceed the risk of hitting the dashboard or windshield on impact; or 2) an infant in a rear-facing child safety seat or a child aged 1 through 12 who needs to ride in the front of the car because the child must be constantly monitored due to a medical condition or because the back seat cannot accommodate the child. This policy has encountered significant resistance, most notably from dealers concerned about product liability exposure. Such concerns may grow even more acute given the automotive industry's mounting financial.

Finally, while advanced airbag designs would be beneficial, it is far from clear that they will ever be $100 \%$ effective in protecting children from airbag-related injuries. Consequently, rear seating of child passengers will remain an important safety objective for years to come.

\section{E. A Better Approach: Using Comprehensive Child Passenger Laws to Avoid the Avoidable}

Despite the drawbacks of current child passenger safety laws, they are already in effect. Accordingly, they serve as an important stepping stone to implementing safer child seating practices. NHTSA has already called for states to improve their existing seat belt laws as follows:

1. Implement primary enforcement.

2. Require all children to be restrained.

94. For a thoughtful discussion of the current economic woes of the industry, see David Cole, Sean McAlinden, Kristen Dziczek, Debra Manager, CAR Research Memorandum: The Impact on the U.S. Economy of a Major Contraction of the Detroit Three Automakers, http://www.cargroup.org/documents/FINALDetroitThreeContractionImpact_3_001.pdf 
3. Require seat belts for children in all seats.

4. Apply seat belt laws to all cars, vans and light trucks traveling in the state, regardless of place of registration. ${ }^{95}$

However, the following measures are also needed to ensure a truly comprehensive approach to protecting child passengers:

5. Require all adults to use seat belts.

6. Expressly require rear seating for children age 12 and under unless no rear seat is available.

7. Require that all car seats, restraints, and belts be used in accordance with federal safety standards and manufacturers' directions.

8. Charge the driver with responsibility for statutory compliance, using significant fines and penalties to maximize compliance.

The "Model Child Seating Legislation" proposed infra uses all of these techniques to optimize child safety. Studies have consistently shown that adults are more likely to wear seat belts when required by law, and adults who buckle up are more likely to buckle their children and also model safe behavior for the child. ${ }^{96}$ For the same reasons, rear seating for children must be expressly mandated since, as demonstrated in the seat belt context, state laws improve compliance when used in place of, or in addition to consumer education campaigns. ${ }^{97}$ Holding the driver responsible for compliance clarifies and facilitates enforcement.

A final recommendation for improving state laws is to link "proper" restraint to federal safety requirements - a connection already articulated by many states. ${ }^{98}$ Critics of this part of the proposal should recognize that, since the inception of motor vehicle safety regulation in the 1960's, both states and the federal government have played active but complementary roles. ${ }^{99}$ The states have taken the lead in laws and regulations which deal with the role of human behavior in safety matters - although they have frequently needed strong federal incentives to do so. ${ }^{100}$ The U.S. Department of Transportation and its subsidiary, NHTSA, have dominated regulation of the design and manufacturing inputs to safety. Consequently, NHTSA often works closely with manufacturers and insurers as well as sponsoring research. ${ }^{101}$ All of this makes new safety interventions more likely to

95. See supra note 73.

96. . See Nat'l Transp. Safety Bd. Study: The Performance and Use of Child Restraint Systems: Seat belts and Airbags for Children in Passenger Vehicles, (U.S. Dept. of Transp. 1996).

97. Id.

98. See supra note 54 and accompanying text.

99. See supra note 48.

100. Id.

101. See, e.g., American Automobile Manufacturers Association, Association of International Automotive Manufacturers, Inc., Automotive Occupant Restraints Council, IIHS, Joint Statement and Recommendation on Advanced Air Bag Technology (1998) (describing collaboration among government, vehicle manufacturers and airbag suppliers to improve airbag safety). 
emerge, be analyzed, and ultimately adopted at the federal rather than state level. Thus, a state law which expressly links proper child restraint to federal safety standards can better evolve over time as new safety measures materialize through improvements in information and technology. In this way, a state law can avert the need for constant updating to account for new developments, a tremendous benefit given the complexity of the legislative process.

A companion to this linkage in the state arena is for federal safety standards explicitly to incorporate seating position into all definitions of "child restraint system" as well as to require such information to be contained in product warnings. Manufacturers should support these state and federal legislative adaptations. If enacted and, more importantly, if enforced, it could improve safety and even reduce product liability claims. Permitting evidence of improper seating position and/or restraint to be used in litigation could serve as an important incentive for safer seating behaviors. A few states already permit a "no seat belt defense" which can result in automatic reductions of all or part of a damage award to an unbelted plaintiff, but in the context of child seating, it may be difficult to justify where the passenger, as a child, is not easily held accountable for decisions regarding seating location or restraint. ${ }^{102}$

Under the framework proposed in this article, parents transporting multiple children may find their vehicles less useful and might need to confront the expense of a larger vehicle. Some parents may communicate less effectively with the child in the rear seat. There may even be occasions when crashes occur during efforts by frustrated parents to control the behavior of a child seated in the rear. To some extent, these and other inconveniences can be addressed by carefully and narrowly crafting exemptions to new child seating laws. For example, front seating of children should be permitted when a rear seat does not exist or is being used at full capacity. Medical reasons for allowing a child to ride in the front, while rare, should be respected in new legislation. Although such exceptions will make these laws more acceptable, it is important to recognize that rear seating laws do impose inconvenience and costs on vehicle owners, parents, and children. Given the risks posed by airbags and the inherent safety advantages of the rear seat, however, the inconvenience and costs are essential to reduce lifethreatening, but readily avoidable risks to child passengers.

\section{F. Model Child Occupant Restraint and Seating Legislation}

Chapter XXX, Section 00:

(a) Definitions. For the purpose of this Section, the following defi-

102. See IIHS-HLDI, Child Restraint, Belt Laws, http://www.iihs.org/laws/state_laws/ restrain.html. 
nitions will control:

(1) A child is any person under the age of legal majority in this state;

(2) An adult is any person who meets or exceeds the legal age of majority in this state;

(3) A motor vehicle shall include any automobile, van carrying less than 10 passengers, or light truck (but not an authorized emergency vehicle or public transportation) which is required by federal law to be equipped with safety belts under federal standards and is traveling in this state, regardless of such motor vehicle's place of registration;

(4) An occupant shall include the driver and any and all passengers within a motor vehicle.

(b) (Adults) Each adult occupant in a motor vehicle shall be restrained by a properly secured and fastened seat belt which is installed and used in accordance with federal safety standards and manufacturers' directions.

(c) (Children age 13 and older) Every driver who transports a child age 13 or older in a motor vehicle shall ensure that such child is restrained by a properly secured and fastened seat belt which is installed and used in accordance with federal safety standards and manufacturers' directions.

(d) (Children age 7 through 12) Every driver who transports a child age 7 through 12 in a motor vehicle shall ensure that such child is seated in a rear passenger seat and restrained by a properly secured and fastened seat belt which is installed and used in accordance with federal safety standards and manufacturers' directions.

(e) (Children age 5 through 6) Every driver who transports a child 5 through 6 years of age and weighing 40 to 60 pounds in a motor vehicle shall seat such child in a child passenger "booster" restraining system which is located in a rear passenger seat and installed and used in accordance with federal safety standards and manufacturers' directions.

(f) (Children age 4 and under) Every driver who transports a child 4 years of age or younger and weighing 40 pounds or less in a motor vehicle shall seat such child in a child passenger restraining system which is located in a rear passenger seat and is installed and used in accordance with federal safety standards and manufacturers' directions.

(g) (Priority in rear seating) In the event that all rear and front passenger seats will be occupied by children age 12 and under, priority in rear seating must be given first to children age 4 and under, second to children age 5 through 6 , third to children aged 7 through 12 , and last to occupants age 13 and older.

(h) (Emergency and medical exemptions) The provisions of this Section shall not apply when emergency attention is required for the child's immediate and personal safety, or where a licensed medical doctor has indicated in writing that the child's medical condition necessitates an exemption from the requirements of this Section. In such instances, the driver shall carry a copy of the medical doctor's determination of the child's med- 
ical exemption from the requirements of this Section.

(i) (Primary enforcement) A violation of this Section shall be considered a primary offense and a motor vehicle may be stopped by a police officer solely for failure to comply with this Section.

(j) (Fines and penalties) Upon a first conviction under this Section, the defendant shall be punished by a fine of not less than $\$ 100.00$. The failure to provide a child restraint system or seat belt for more than one child in the same vehicle at the same time as required by this Section shall be treated as separate offenses.

Upon a subsequent conviction of an offense under this Section, the defendant shall be punished by a fine of not less than $\$ 250.00$ per offense plus all costs of court.

(k) (Evidentiary effect) A violation of this Section may be considered as evidence of the driver's and/or adult occupant's comparative or contributory negligence in any civil suit or of the driver's or adult passenger's criminal negligence or recklessness in any criminal action arising out of any motor vehicle accident. A violation of this Section may not be considered as evidence of a child's comparative or contributory negligence or recklessness in any civil or criminal action.

(l) (Collection of Data) The court imposing a fine for any violation under this Section shall forward a record of the disposition of the cases annually to the Department of Public Safety for the sole purpose of data collection on a county by county basis.

\section{CONCLUSION}

For adults, airbags have been a major innovation in motor vehicle safety. Their attendant risks to children will surely be reduced over time as technology advances, but may never be completely eradicated. In the meantime, a simple and effective solution is available: seat children in the rear of the vehicle. Government should not shirk its special obligation to protect children, especially since the intervention is so straightforward. Better state laws can reduce pediatric airbag injuries, ease enforcement of seat belt requirements, and enhance overall child safety.

This objective should be accomplished through consumer education campaigns as well as carefully drafted state child restraint laws and federal safety standards. The "message" of all educational, legislative and regulatory efforts must tightly and consistently integrate seating position with seat belt use. State laws must be primarily enforceable and require rear seating as an essential feature of proper child restraint for all children through the age of 12. The statutory requirement of "proper child restraint" must include seating location and reflect evolving federal safety standards. In turn, federal standards must incorporate seating location into all child restraint provisions. It is hoped that such a comprehensive strategy will reduce the hazards of airbags for child passengers while preserving their safety advan- 
tages for adults. 